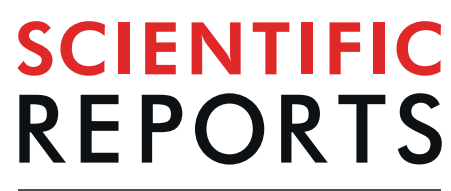

natureresearch

\title{
Effect of manure and mineral fertilisers on the content of light and heavy polycyclic aromatic hydrocarbons in soil
}

\begin{abstract}
Sławomir Krzebietke $\mathbb{D}^{1 *}$, Ewa Mackiewicz-Walec ${ }^{1}$, Stanisław Sienkiewicz ${ }^{1}$ \& Dariusz Załuski ${ }^{2}$
A study was conducted to explore the effects of fertilisation with farmyard manure (FYM) and mineral fertilisers on the content of PAHs in soil. The analyses were made on soil samples (collected in 19982009) from a long-term field experiment set up in 1986 in Bałcyny near Ostróda. The content of light and heavy polycyclic aromatic hydrocarbons was determined on a gas chromatograph coupled with an FID detector. The analytical data were processed statistically according to an analysis of variance with repeated measurements. The content of light and heavy polycyclic aromatic hydrocarbons was significantly higher in soil fertilised with FYM than in soil nourished only with mineral fertilisers. The effect of increasing doses of potassium on total light PAHs in soil depended on a fertilisation system there was either a distinct decrease in soil fertilised with mineral substances alone or a slight increase in soil fertilised with manure. Regular soil liming significantly raised the $\sum$ of heavy PAHs in soil treated with manure but significantly decreased it in soil supplied only mineral fertilisers.
\end{abstract}

Polycyclic aromatic hydrocarbons (PAHs) are included into the most important environmental pollutants of natural and antropogenic origin including three types of transformation: biological, pyrogenic and petrogenic ${ }^{1}$. It is well documented that PAHs have toxic, carcinogenic and even mutagenic effects on life organisms ${ }^{1-4}$. Although the human activities contributes to the PAH presence in the elevated concentrations in soils, the microorganisms such as bacteria, fungi and algae can successfully participate in the PAH biodegradation ${ }^{1,5}$. The effective way to decontaminate the PAHs including some physical, chemical and biological (bioremediation, phytoremediation) processes can lead to complete mineralization into $\mathrm{CO}_{2}, \mathrm{H}_{2} \mathrm{O}$ and biomass ${ }^{6}$. Bioavailability of contaminants in soil depends on a number of factors, including the soil properties (content of organic carbon, $\mathrm{pH}$, porosity, composition of the soil solution), characteristics of compounds (molecular structure, solubility in water, volatility, value of the KOW and KOC coefficients) and the biology of organisms (habitat, morphology, age, development stage, viability, etc.) and climate (temperature, moisture) as well as the presence of other compounds ${ }^{7}$. PAHs have a tendency to persist in the environment. PAHs with a low molecular weight are more easily biodegradable than the ones with a higher molecular weight ${ }^{8,9}$. The half-life of low-molecular-weight (LMW) PAHs, e.g. phenanthrene, is from 16 to 126 days, while high-molecular-weight (HMW) PAHs have a longer half-life period, e.g. benzo(a) pyrene can last for up to 1400 days ${ }^{10}$. According to Włóka et al. ${ }^{11}$, polycyclic aromatic hydrocarbons with a lower molecular weight are more resistant to biodegradation processes, and their presence is more stable than that of high-molecular-weight PAHs.

PAHs are very mobile, ubiquitous, and a possible grave threat to the environment ${ }^{12,13}$. They are generated as by-products of many chemical processes. The source of these contaminants could be any process involving incomplete incineration of organic compounds. Polycyclic aromatic hydrocarbons present in man's environment are mostly derived from anthropogenic sources ${ }^{14}$, while the contamination with PAHs from natural sources corresponds to the so-called 'natural background'. PAHs produced by natural biosynthesis have a less developed structure than the ones from anthropogenic sources ${ }^{15}$.

\footnotetext{
${ }^{1}$ Department of Agricultural Chemistry and Environmental Protection, Faculty of Environmental Management and Agriculture, University of Warmia and Mazury in Olsztyn, Olsztyn, Poland. ${ }^{2}$ Department of Plant Breeding and Seed Production, Faculty of Environmental Management and Agriculture, University of Warmia and Mazury in Olsztyn, Olsztyn, Poland. *email: slawomir.krzebietke@uwm.edu.pl
} 


\begin{tabular}{|l|l|l|l|}
\hline Source of variation & df & 9 light PAHs & 7 heavy PAHs \\
\hline Manure (O) & 1 & $* *$ & $* *$ \\
\hline Block (B) & 2 & ns & ns \\
\hline Mineral fertilisation $(\mathrm{M})$ & 7 & $* *$ & $* *$ \\
\hline O x M & 7 & $* *$ & $* *$ \\
\hline Error 1 & 30 & - & - \\
\hline Research years (Y) & 11 & $* *$ & $* *$ \\
\hline Y x O & 11 & $* *$ & $* *$ \\
\hline Y x B & 22 & ns & ns \\
\hline Y x M & 77 & $* *$ & $* *$ \\
\hline Y x O x M & 77 & $* *$ & $* *$ \\
\hline Error 2 & 330 & - & - \\
\hline
\end{tabular}

Table 1. Tow-factorial analysis of variance of the PAHs content in a system with repeated measurements. $* *$ Level of significance $\mathrm{p}<0.01 ; \mathrm{ns}$ - non-significant; $\mathrm{df}$ - degrees of freedom.

Several factors may reduce the rate and scope of biodegradation of PAHs in soil ${ }^{16-21}$, e.g. content of organic matter in soil, content of nutrients, fertilisation, the C:N:P ratio, presence and abundance of microorganisms, acceptors of electrons, temperature, moisture, $\mathrm{pH}$ and content of oxygen.

The aim of the study was to evaluate the effect of long-term fertilisation with manure and mineral fertilisers on the content of light and heavy PAHs in soil $(0-30 \mathrm{~cm})$ during three crop rotation cycles.

\section{Results and discussion}

Organic fertilisers increase the content of organic matter, whereas mineral fertilisation raises the load of biogenic compounds and improves the cation exchange capacity, and liming stabilises the reaction of the soil environment $^{22}$. On the other hand, fertilisers are a potential source of pollutants, including PAHs ${ }^{11}$. The statistical analyses carried out during the study demonstrated a highly significant influence of manure $(\mathrm{O})$ and differentiated mineral fertilisation $(\mathrm{M})$ as well as the interaction of these factors $(\mathrm{O} \times \mathrm{M})$ on the content of light PAHs (naphthalene, acenaphthene, acenaphthylene, fluorene, anthracene, fluoranthene, pyrene, chrysene) and heavy PAHs (benzo(a)anthracene, benzo(a)pyrene, benzo(b)fluoranthene, benzo(k)fluoranthene, benzo(g,h,i)perylene, indeno(1,2,3-cd)pyrene, dibenzo(a,h)anthracene) in soil (Table 1). Variation in the content of light and heavy PAHs in soil proved to be highly variable in the research years.

Sum of light PAHs. The content of light polycyclic aromatic hydrocarbons (naphthalene, acenaphthylene, fluorene, anthracene, phenathrene, fluoranthene, pyrene, chrysene) was distinctly greater in soil regularly fertilised with FYM $\left(114.2 \mu \mathrm{g} \cdot \mathrm{kg}^{-1}\right.$ on average) than in soil fertilised only with mineral fertilisers $\left(76.3 \mu \mathrm{g} \cdot \mathrm{kg}^{-1} \mathrm{on}\right.$ average) (Fig. 1A, Table 2).

Higher doses of nitrogen significantly increased the content of light polycyclic aromatic hydrocarbons in soil (Fig. 2A, Table 2). A completely reverse effect was produced by potassium, as this element decreased the average content of the analysed substances in soil, and magnesium produced a comparably positive impact. Based on the statistical computations (transformation and elimination of extreme data), it can be concluded that liming is a treatment which leads to a decrease in the soil content of PAHs.

Higher doses of nitrogen contributed to an elevated accumulation of light PAHs in soil fertilised with FYM and with mineral fertilisers alone (Fig. 2A, Table 2). Based on the research results, it can be demonstrated that potassium and magnesium under exclusive mineral fertilisation can limit the accumulation of these contaminants in soil. A reverse effect of the above elements was observed in soil fertilised with FYM and mineral fertilisers (Fig. 2B). Higher doses of nitrogen and magnesium in more fertile soil (nourished regularly with manure) do not create the conditions for microorganisms to use PAHs as a source of energy. Furthermore, a higher supply of available forms of potassium and magnesium in soil receiving only mineral fertilisers can contribute to a higher count of microorganisms. As the microorganisms have less organic matter, they are forced to take advantage of PAHs. It turned out that the calculated average amounts of light PAHs in soil over the period of 12 years are not the best measure to show the variability of this characteristic. It was not until the applied statistical model was employed that a more precise assessment of the soil content of PAHs depending on mineral fertilisation was achievable. On the basis of transformed data, and having eliminated the extreme values, it can be concluded that soil liming under the intensive manure fertilisation conditions can reduce considerably the content of PAHs in soil. No such beneficial effect of liming was observed in soil which received only mineral fertilisation.

Sum of heavy PAHs. Maliszewska-Kordybach et al. ${ }^{23,24}$; Yang et al. ${ }^{25}$ and Klimkowicz-Pawlas et al. ${ }^{26}$ report on higher concentrations of heavy PAHs than light PAHs in soil. Based on our trials, it is difficult to confirm this dependence, although the mean concentrations calculated for the 12-year-long experimental period showed that the content of heavy PAHs was only slightly higher than that of light ones (Fig. 1A,B, Tables 2 and 3). It was also possible to notice that the content of heavy PAHs in soil fertilised with manure was slightly higher than in soil nourished only with mineral fertilisers (Fig. 1B, Table 3). According to MARQuÈs et al. ${ }^{27}$, PAHs with low molecular mass are more rapidly biodegraded when the temperature and light intensity increase. Similar results were reported by Park et al. ${ }^{8}$. In a study carried out by Mazur et al. ${ }^{28}$, the most abundant PAHs in soil were the 
A

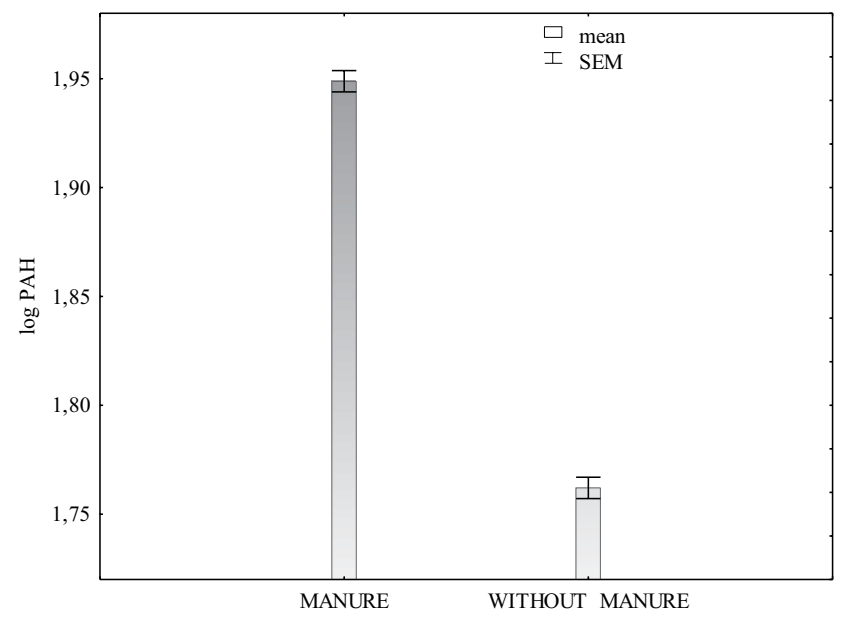

B

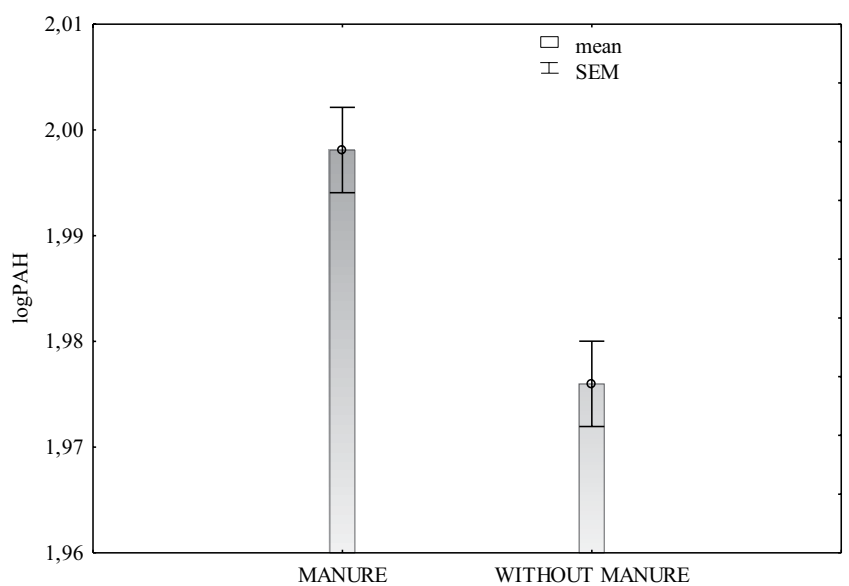

Figure 1. Sum of light PAHs (A) and sum of heavy PAHs (B) in soil fertilised and not fertilised with FYM (transformed data from the years 1998-2009).

\begin{tabular}{|c|c|c|c|c|c|c|c|c|c|}
\hline Variants & $\mathrm{N}_{0} \mathrm{P}_{0} \mathrm{~K}_{0}$ & $\mathbf{N}_{1} \mathbf{P}_{1} \mathbf{K}_{1}$ & $\mathrm{~N}_{2} \mathbf{P}_{1} \mathrm{~K}_{1}$ & $\mathbf{N}_{3} \mathbf{P}_{1} \mathbf{K}_{1}$ & $\mathbf{N}_{2} \mathbf{P}_{1} \mathbf{K}_{2}$ & $\mathbf{N}_{2} \mathrm{P}_{1} \mathrm{~K}_{3}$ & $\mathrm{~N}_{2} \mathrm{P}_{1} \mathrm{~K}_{2} \mathrm{Mg}$ & $\mathrm{N}_{2} \mathrm{P}_{1} \mathrm{~K}_{2} \mathrm{MgCa}$ & Mean \\
\hline \multicolumn{10}{|c|}{ Sum of light PAHs in soil $\left[\boldsymbol{\mu g} \cdot \mathrm{kg}^{-1}\right]$} \\
\hline Manure & 97.1 & 99.0 & 115.8 & 112.9 & 119.1 & 116.1 & 119.4 & 133.9 & 114.2 \\
\hline Without manure & 78.6 & 87.6 & 81.4 & 86.6 & 71.1 & 86.0 & 61.9 & 57.3 & 76.3 \\
\hline Mean & 87.8 & 93.3 & 98.6 & 99.7 & 95.1 & 101.0 & 90.7 & 95.6 & - \\
\hline
\end{tabular}

Table 2. Content of the sum of light PAHs in soil in the years 1998-2009 depending on the application of farmyard manure $(\mathrm{O})$, mineral fertilisers $(\mathrm{M})$ and interaction of $\mathrm{O} \times \mathrm{M}$.

three-ringed ones. Also, Włóka et al. ${ }^{11}$ as well as Zhao et al. ${ }^{29}$ demonstrated the dominance of 2- and 3-ringed PAHs.

The content of total heavy PAHs (benzo(a)anthracene, benzo(a)pyrene, benzo(b)fluoranthene, benzo(k) fluoranthene, benzo(g,h,i)perylene, indeno(1,2,3-cd)pyrene, dibenzo(a,h)anthracene), similarly to the sum of light PAHs, increased under the influence of larger doses of nitrogen (Fig. 3A, Table 3). The highest soil content of heavy PAHs $\left(132.7 \mu \mathrm{g} \cdot \mathrm{kg}^{-1}\right)$ was determined after the application of the highest nitrogen dose. Potassium did not have any significant effect on the soil content of PAHs. Regular soil liming had a positive effect, diminishing the content of the above pollutants in soil.

Changes in the content of heavy PAHs in soil depending on mineral fertilisation carried out with or without manure ran a completely different course than those concerning light PAHs (Fig. 3B, Table 3). The difference was the greatest in limed soil. Soil liming carried out on soil fertilised exclusively with mineral fertilisers very strongly reduced the content of heavy PAHs in soil, while having an opposite effect in soil fertilised also with farmyard manure. In addition, lower amounts of PAHs were determined in soil regularly fertilised with manure and the 

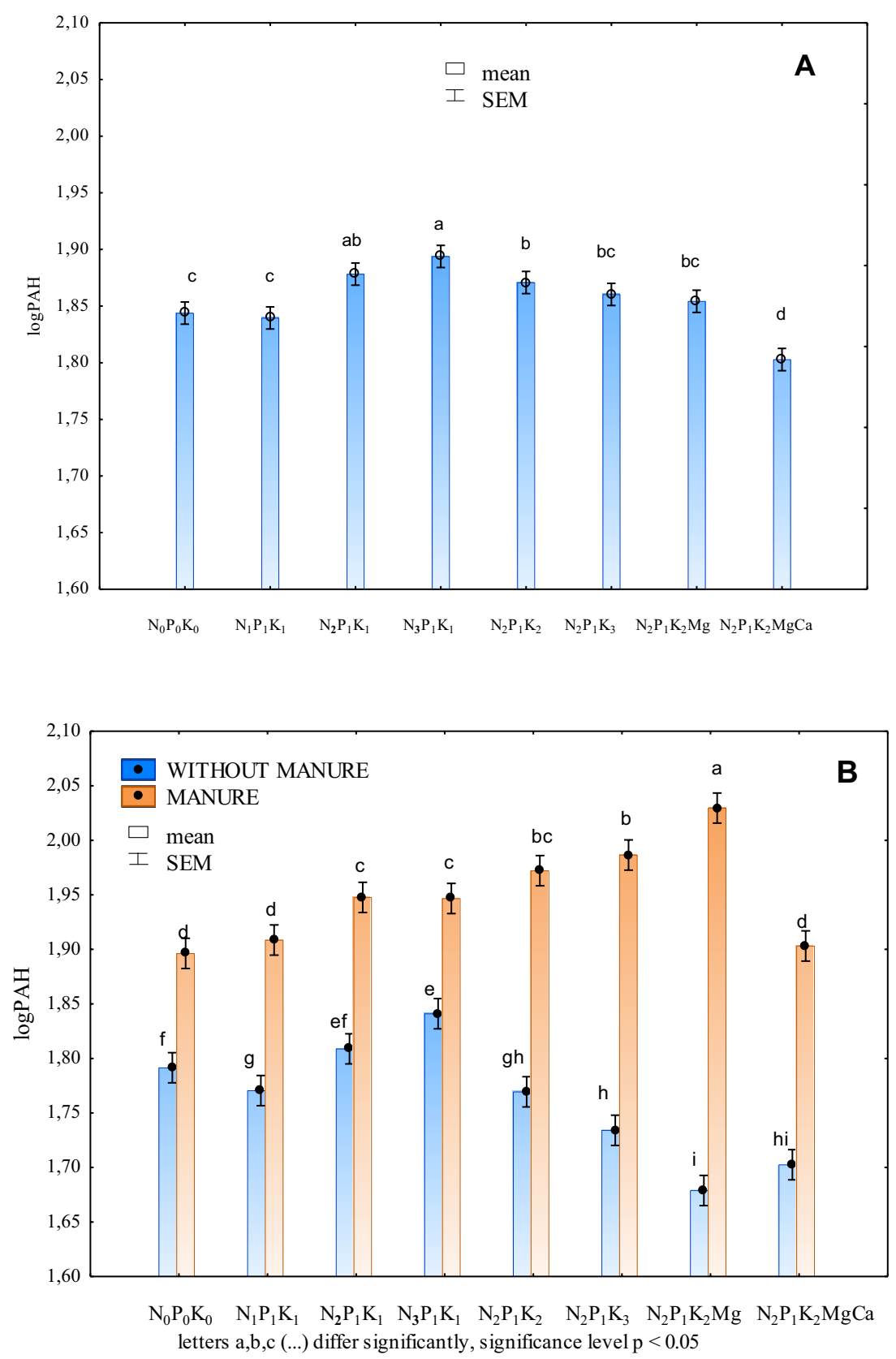

Figure 2. Sum of light PAHs in soil depending on: mineral fertilisation (A) and manure-mineral and mineral fertilisation (B) (transformed data from the years 1998-2009).

\begin{tabular}{|c|c|c|c|c|c|c|c|c|c|}
\hline Variants & $\mathrm{N}_{0} \mathrm{P}_{0} \mathrm{~K}_{0}$ & $\mathrm{~N}_{1} \mathrm{P}_{1} \mathrm{~K}_{1}$ & $\mathrm{~N}_{2} \mathrm{P}_{1} \mathrm{~K}_{1}$ & $\mathrm{~N}_{3} \mathrm{P}_{1} \mathrm{~K}_{1}$ & $\mathbf{N}_{2} \mathbf{P}_{1} \mathbf{K}_{2}$ & $\mathrm{~N}_{2} \mathrm{P}_{1} \mathrm{~K}_{3}$ & $\mathrm{~N}_{2} \mathrm{P}_{1} \mathrm{~K}_{2} \mathrm{Mg}$ & $\mathrm{N}_{2} \mathrm{P}_{1} \mathrm{~K}_{2} \mathrm{MgCa}$ & Mean \\
\hline \multicolumn{10}{|c|}{ Sum of heavy PAHs in soil $\left[\mu \mathrm{g} \cdot \mathrm{kg}^{-1}\right]$} \\
\hline Manure & 115.1 & 97.8 & 127.4 & 137.0 & 127.8 & 109.0 & 119.4 & 127.2 & 120.1 \\
\hline Without manure & 93.3 & 102.9 & 108.4 & 128.3 & 112.2 & 124.1 & 129.4 & 98.6 & 112.2 \\
\hline Mean & 104.2 & 100.4 & 118.0 & 132.7 & 120.1 & 116.5 & 124.4 & 112.9 & - \\
\hline
\end{tabular}

Table 3. Content of the sum of heavy PAHs in soil in the years 1998-2009 depending on the application of farmyard manure $(\mathrm{O})$, mineral fertilisers $(\mathrm{M})$ and interaction of $\mathrm{O} \times \mathrm{M}$.

highest dose of potassium or $\mathrm{N}_{2} \mathrm{P}_{1} \mathrm{~K}_{2} \mathrm{Mg}$ than in soil fertilised only with mineral fertilisers. Same as for light PAHs, the content of heavy PAHs in soil was strongly affected by nitrogen. In the soil fertilised only with mineral fertilisers with a dose of nitrogen, the content of heavy PAHs increased proportionally. It is possible to conclude that manure had a weaker effect on the content of heavy PAHs than on the content of light PAHs in soil. 

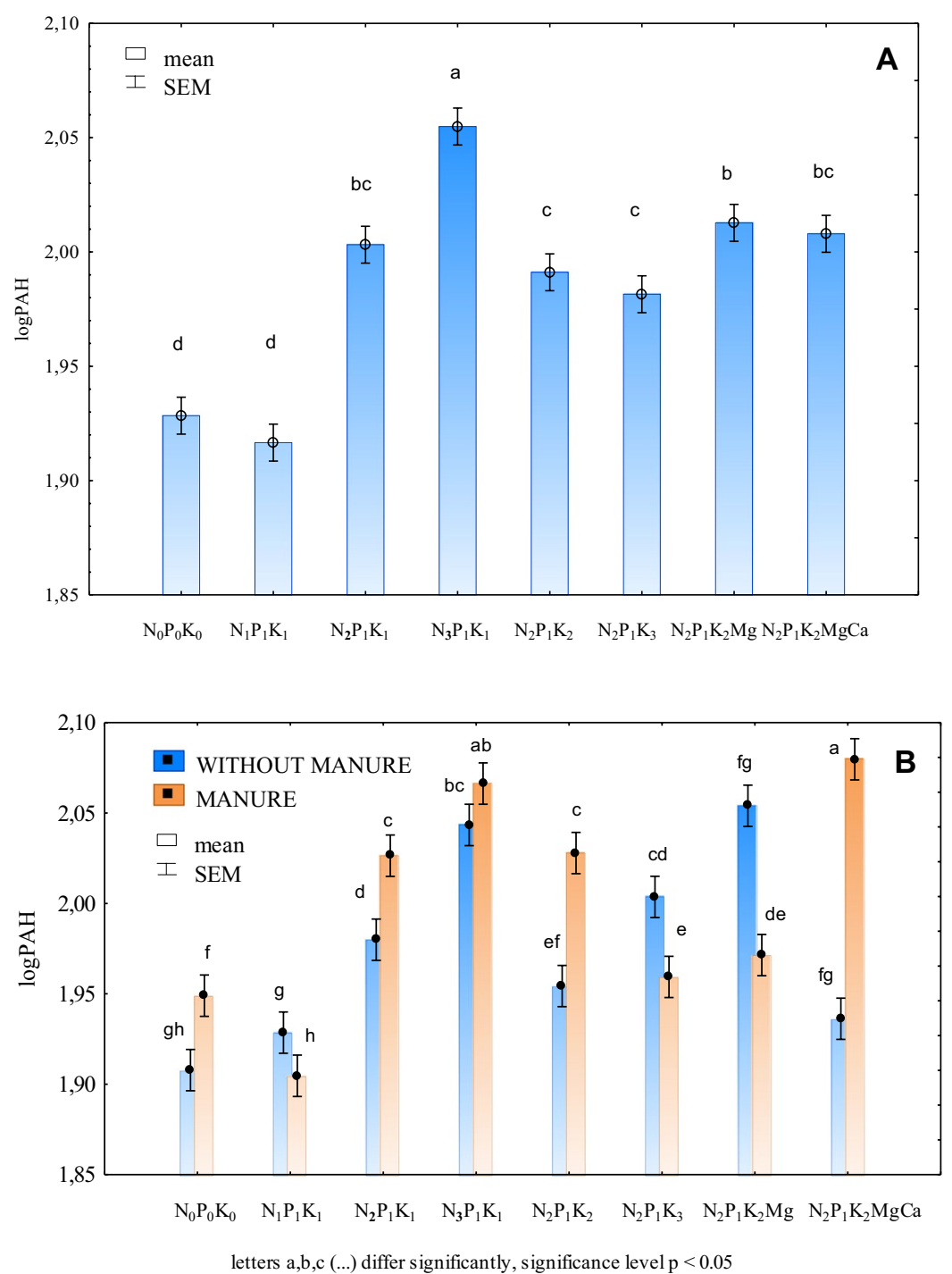

Figure 3. Sum of heavy PAHs in soil depending: on mineral fertilisation (A) and manure-mineral and mineral fertilisation (B) (transformed data from the years 1998-2009).

According to Regulation of the Minister of the Environment of September 1, 2016 on the method of conducting soil pollution assessment (Journal of Laws of 2016, item 1395) (30 $^{30}$ in Poland is an obligation to identify 10 compounds from the PAH group: naphthalene, anthracene, chrysene, benzo(a)anthracene, benzo(a)pyrene, benzo(b) fluoranthene, benzo(k)fluoranthene, benzo(g,h,i)perylene, indeno(1,2,3-cd)pyrene, dibenzo(a,h)anthracene on an arable land in the $0-30 \mathrm{~cm}$ layer. The content of the sum of the above mentioned compounds should not exceeded $1400 \mu \mathrm{g} \cdot \mathrm{kg}^{-1}$ of soil. According to the IUNG (Institute of Soil Science and Plant Cultivation) classification Kabata-Pendias et. al..$^{31}$ and Siebielec et. al. ${ }^{32}$ proposed the division of pollutant content of the $\sum 16 \mathrm{PAH}$ as follows: below $200 \mu \mathrm{g} \cdot \mathrm{kg}^{-1}$ of soil as natural content, $200-600 \mu \mathrm{g} \cdot \mathrm{kg}^{-1}$ of soil as elevated but not contaminated soil, whereas the range of $600-1000 \mu \mathrm{g} \cdot \mathrm{kg}^{-1}$ of soil as low-contaminated at which content the restrictions on plant cultivation should be considered, especially for children and infants. An assessment of long-term use of natural fertilisers (manure) at a dose of $40 \mathrm{t} \cdot \mathrm{ha}^{-1}$ every two years as a source of PAH in soil, despite a slight increase in the $\sum 16 \mathrm{PAH}$ compared to mineral fertilisation, is safe for the soil environment if it is the only source of these pollutants. When assessing the average level of PAH contaminations in soils fertilised with both natural and mineral fertilisers, there were no exceedances of the assessed compounds that could have a negative impact on increasing their share in soil above the applicable standard content.

\section{Conclusions}

Regular application of large doses of manure ( $40 \mathrm{t} \mathrm{ha}^{-1}$ every two years) can raise the load of PAHs in soil. In our study, the content of light and heavy PAHs was higher in soil fertilised with manure than in soil fertilised only with mineral fertilisers. The impact of increasing doses of potassium on the sum of light PAHs in soil depended on the fertilisation regime - there was a distinct decrease in soil fertilised only with mineral fertilisers and a slight increase in soil fertilised with manure. Regular soil liming significantly increase the content of the $\sum$ of heavy PAHs in soil fertilised with manure while decreasing it significantly in soil fertilised only with mineral fertilisers. 


\begin{tabular}{|c|c|c|c|c|c|}
\hline \multicolumn{3}{|c|}{ Series with FYM } & \multicolumn{3}{|c|}{ Series without FYM } \\
\hline $\begin{array}{l}\text { Block } \\
\text { (repeat) }\end{array}$ & \begin{tabular}{|l|} 
Plot \\
number
\end{tabular} & $\begin{array}{l}\text { Mineral fertilisation } \\
\text { (Table 5) }\end{array}$ & \begin{tabular}{|l|}
$\begin{array}{l}\text { Block } \\
\text { (repeat) }\end{array}$ \\
\end{tabular} & \begin{tabular}{|l|} 
Plot \\
number
\end{tabular} & \begin{tabular}{|l} 
Mineral fertilisation \\
(Table 5)
\end{tabular} \\
\hline \multirow{8}{*}{ I } & 1 & 3 & \multirow{8}{*}{ I } & 48 & 4 \\
\hline & 2 & 7 & & 47 & 6 \\
\hline & 3 & 4 & & 46 & 3 \\
\hline & 4 & 1 & & 45 & 5 \\
\hline & 5 & 8 & & 44 & 1 \\
\hline & 6 & 2 & & 43 & 2 \\
\hline & 7 & 6 & & 42 & 8 \\
\hline & 8 & 5 & & 41 & 7 \\
\hline \multirow{8}{*}{ II } & 9 & 4 & \multirow{8}{*}{ II } & 40 & 5 \\
\hline & 10 & 6 & & 39 & 8 \\
\hline & 11 & 7 & & 38 & 6 \\
\hline & 12 & 1 & & 37 & 3 \\
\hline & 13 & 8 & & 36 & 7 \\
\hline & 14 & 2 & & 35 & 2 \\
\hline & 15 & 3 & & 34 & 4 \\
\hline & 16 & 5 & & 33 & 1 \\
\hline \multirow{8}{*}{ III } & 17 & 1 & \multirow{8}{*}{ III } & 32 & 8 \\
\hline & 18 & 7 & & 31 & 5 \\
\hline & 19 & 8 & & 30 & 7 \\
\hline & 20 & 2 & & 29 & 4 \\
\hline & 21 & 4 & & 28 & 1 \\
\hline & 22 & 6 & & 27 & 5 \\
\hline & 23 & 3 & & 26 & 2 \\
\hline & 24 & 5 & & 25 & 6 \\
\hline
\end{tabular}

Table 4. Design of the field trial.

However, lime is not a PAH carrier, it was used only to maintain the proper soil pH, i.e. slightly acidic conditions ( $\mathrm{pH}$ 5.5-6.6) which, in turn, were more favorable for e.g. faster mineralization of the organic matter. Probably, bacteria could then use more easily available food compounds from the manure used, instead of use hardly available carbon from PAHs.

\section{Material and methods}

Description of the field experiment. The experiment was set up in 1986, in the village Bałcyny near Ostróda, the Province of Warmia and Mazury in Poland. The experiment was established according to the design described in Table 4, with three replications (blocks), on grey-brown podzolic soil developed over light loam and classified in the Polish taxonomy as class IIIa, very good rye complex (Haplic Luvisols, IUSS Working Group $\mathrm{WRB}^{33}$ ). Based on the particle size distribution, the soil was classified as sandy loam according to United States Department of Agriculture (USDA).

The experiment comprised fertilisation with farmyard manure (from cows) and mineral fertilisers or with mineral fertilisers alone. Doses of nutrients in mineral fertilisers (ammonium nitrate $(\mathrm{N})$, triple granuled superphosphate $46 \%\left(\mathrm{P}_{2} \mathrm{O}_{5}\right)$, potassium salt $60 \%\left(\mathrm{~K}_{2} \mathrm{O}\right)$ lime $(\mathrm{CaO})$, kizerite $\left.27 \% \mathrm{MgO}\right)$ were on the same levels in both fertilisation regimes. Crops were cultivated in the following rotation sequence: sugar beet, spring barley, maize, and spring wheat. The mineral fertilisation regime is presented in Table 5. Prior to the experiment, $1 \mathrm{~kg}$ of soil contained available nutrients: $100.0 \mathrm{mg} \mathrm{K}, 53.2 \mathrm{mg} \mathrm{Mg}, 41.3 \mathrm{mg} \mathrm{P}, 7.9 \mathrm{~g}$ organic carbon, and $0.79 \mathrm{~g}$ total nitrogen, while the soil reaction was slightly acid at $\mathrm{pH} \mathrm{KCl}\left(1 \mathrm{~mol} \cdot \mathrm{dm}^{-3}\right)=6.2$. Lime in the form of $\mathrm{CaO}$ was applied in an amount of $2.5 \mathrm{t} \cdot \mathrm{ha}^{-1}$ every four years, after harvesting spring wheat (variant 8 ). Farmyard manure was applied in a dose of $40 \mathrm{t} \cdot \mathrm{ha}^{-1}$ every other year, under sugar beet and maize. Spring barley and spring wheat were grown a year after the application of FYM. The content of mineral components and PAHs in FYM were presented in Table 6.

Analytical methods. The research material consisted of soil samples collected in 1998-2009, from a long-term, controlled field experiment, carried out in Bałcyny since 1986. The soil was sampled with a soil sampler, each time obtaining around $1 \mathrm{~kg}$ of soil. Having been dried to the air-dry state, i.e. subjected to dry-air drying at room temperature, each soil sample was sifted through a $2 \mathrm{~mm}$ mesh sieve.

The content of heavy and light molecular weight polycyclic aromatic hydrocarbons was determined on a gas chromatograph - mass spectrometer Trace GC Ultra ITQ900 coupled with an autosampler TRIPlus (Fisher Scientific) manufactured by THERMO, and equipped with an FID detector. An analysis of the content of polycyclic aromatic hydrocarbons (PAHs) was accomplished after one-hour extraction of $20 \mathrm{~g}$ of soil with $20 \mathrm{~cm}^{3}$ of acetonitrile, using an ultrasound washer and horizontal shaker. The extract thus obtained $\left(10 \mathrm{~cm}^{3}\right)$ was decanted and preliminarily purified on an MPW-350R centrifuge and a solid phase extract SPE station. SPE- $\mathrm{NH}_{2} / \mathrm{C} 18$ 


\begin{tabular}{|c|c|c|c|c|c|}
\hline \multirow[b]{3}{*}{ No } & \multirow[b]{3}{*}{ Variant } & \multicolumn{4}{|c|}{ Sugar beet Spring barley Maize Spring wheat* } \\
\hline & & $\mathbf{N}$ & $\mathbf{P}$ & $\mathbf{K}$ & $\mathrm{Mg}$ \\
\hline & & \multicolumn{4}{|l|}{ Dose $\left[\mathrm{kg} \cdot \mathrm{ha}^{-1}\right]$} \\
\hline 1 & $\mathrm{~N}_{0} \mathrm{P}_{0} \mathrm{~K}_{0}$ & 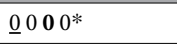 & $\underline{0} * 0$ & 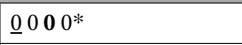 & $\underline{0} 0 * \mathbf{0}$ \\
\hline 2 & $\mathrm{~N}_{1} \mathrm{P}_{1} \mathrm{~K}_{1}$ & $\underline{60} 306040^{*}$ & $\underline{34.9 * 26.2}$ & $\underline{66.4} 33.249 .824 .9^{*}$ & $\underline{0} 0 * \mathbf{0}$ \\
\hline 3 & $\mathrm{~N}_{2} \mathrm{P}_{1} \mathrm{~K}_{1}$ & $\underline{120} 6012080^{*}$ & $\underline{34.9 * 26.2}$ & $\underline{66.4} 33.249 .824 .9^{*}$ & $\underline{0} 0 * \mathbf{0}$ \\
\hline 4 & $\mathrm{~N}_{3} \mathrm{P}_{1} \mathrm{~K}_{1}$ & $\underline{180} 90180120 *$ & $\underline{34.9 * 26.2}$ & $\underline{66.4} 33.249 .824 .9^{*}$ & $\underline{0} 0 * \mathbf{0}$ \\
\hline 5 & $\mathrm{~N}_{2} \mathrm{P}_{1} \mathrm{~K}_{2}$ & $\underline{120} 6012080^{*}$ & $34.9 * 26.2$ & $\underline{132.8} 66.499 .749 .8^{*}$ & $\underline{0} 0 * \mathbf{0}$ \\
\hline 6 & $\mathrm{~N}_{2} \mathrm{P}_{1} \mathrm{~K}_{3}$ & $\underline{120} 6012080^{*}$ & $\underline{34.9 * 26.2}$ & $\underline{199.3} 99.7149 .774 .7^{*}$ & $\underline{0} 0 * 0$ \\
\hline 7 & $\mathrm{~N}_{2} \mathrm{P}_{1} \mathrm{~K}_{2} \mathrm{Mg}$ & $\underline{120} 6012080^{*}$ & $\underline{34.9} * 26.2$ & $\underline{132.8} 66.499 .749 .8^{*}$ & $\underline{48.2} 18.1 * 24,1$ \\
\hline 8 & $\mathrm{~N}_{2} \mathrm{P}_{1} \mathrm{~K}_{2} \mathrm{MgCa}$ & $\underline{120} 6012080^{*}$ & $\underline{34.9 * 26.2}$ & $\underline{132.8} 66.499 .749 .8^{*}$ & $\underline{48.2} 18.1 * \mathbf{2 4 , 1}$ \\
\hline
\end{tabular}

Table 5. Mineral fertilisation regime.

\begin{tabular}{|c|c|c|c|c|c|}
\hline \multicolumn{6}{|c|}{ Mineral composition in FYM } \\
\hline \multicolumn{2}{|c|}{ macroelements } & \multicolumn{2}{|l|}{ microelements } & \multicolumn{2}{|l|}{ metals } \\
\hline \multicolumn{2}{|l|}{$\mathrm{g} \cdot \mathrm{kg}^{-1} \mathrm{DM}$ (dry matter) } & \multicolumn{4}{|l|}{$\mathrm{mg} \cdot \mathrm{kg}^{-1} \mathrm{DM}$} \\
\hline $\mathrm{N}$ (nitrogen) & 17.5 & $\mathrm{Cu}$ (copper) & 36.8 & Cd (cadmium) & 0.26 \\
\hline $\mathrm{P}$ (phosphorous) & 6.7 & Zn (zinc) & 223 & Hg (mercury) & 0.06 \\
\hline $\mathrm{K}$ (potassium) & 11.4 & Co (cobalt) & 5 & $\mathrm{~Pb}$ (lead) & $<2.50$ \\
\hline $\mathrm{Mg}$ (magnesium) & 6.1 & Mn (manganese) & 334 & $\mathrm{Cr}$ (chromium) & 3.51 \\
\hline $\mathrm{Ca}$ (calcium) & 18.2 & Mo (molibdenium) & $<5.00$ & Ni (nickiel) & 6.64 \\
\hline S (sulphur) & 4.9 & & & & \\
\hline \multicolumn{6}{|c|}{ Content of PAHs in FYM } \\
\hline \multicolumn{2}{|c|}{ light } & \multicolumn{2}{|l|}{ heavy } & \multicolumn{2}{|l|}{ sum } \\
\hline \multicolumn{6}{|l|}{$\mu \mathrm{g} \cdot \mathrm{kg}^{-1} \mathrm{DM}$} \\
\hline NAP (naphthalene) & $<10.0$ & (BaA) benzo(a)anthracene & 25 & \multirow{9}{*}{\multicolumn{2}{|c|}{$\sum 16$ PAHs -307.0}} \\
\hline ACE (acenaphthene) & $<10.0$ & $(\mathrm{BaP})$ benzo(a)pyrene & 21 & & \\
\hline ACY (acenaphthylene) & $<10.0$ & (BbF) benzo(b)fluoranthene & 45 & & \\
\hline FLU (fluorene) & $<10.0$ & (BkF) benzo(k)fluoranthene & 22 & & \\
\hline ANT (anthracene) & $<10.0$ & (BghiP) benzo(g,h,i)peryleme & 16 & & \\
\hline PHN (phenanthrene) & 40 & (InP) indeno(1,2,3,-cd)pyrene & 18 & & \\
\hline FTH (fluoranthene) & 59 & (DahA) dibenzo(a,h)anthracene & 10 & & \\
\hline PYR (pyrene) & 37 & & & & \\
\hline CHR (chrysene) & 24 & & & & \\
\hline
\end{tabular}

Table 6. The mean mineral composition and content of PAHs in farmyard manure.

cartridges with the adsorbent weight of $1500 \mathrm{mg}$ and the capacity of $6 \mathrm{~cm}^{3}$ were used. $10 \mathrm{~cm}^{3}$ of methanol was applied to flush the PAHs from the adsorbent, after which the extract was concentrated in a neutral gas (nitrogen) atmosphere up to the volume of $0.2 \mathrm{~cm}^{3}$. The samples prepared as described above were subjected to determinations of PAHs with the GC technique, using an FID detector mounted on an Rxi-5ms column $30 \mathrm{~m}$ in length, and the inner diameter of $0.25 \mathrm{~mm}$, where the walls were coated with a $0.25-\mu \mathrm{m}$ thick layer of liquid stationary phase (SCOT column technology). He at a constant flow rate $\left(3 \mathrm{~cm}^{3} \cdot \mathrm{min}^{-1}\right)$, and $\mathrm{H}_{2}$, air and $\mathrm{N}_{2}$ at the respective flow rates of 35,350 and $30 \mathrm{~cm}^{3} \cdot \mathrm{min}^{-1}$ ) served as carrier gases. The temperature regime was as follows: $0-100^{\circ} \mathrm{C}-0.2 \mathrm{~min} ; 50^{\circ} \mathrm{C} \cdot \mathrm{min}^{-1}-143^{\circ} \mathrm{C}-1.5 \mathrm{~min} ; 8^{\circ} \mathrm{C} \cdot \mathrm{min}^{-1}-180^{\circ} \mathrm{C}-0.4 \mathrm{~min} ; 100^{\circ} \mathrm{C} \cdot \mathrm{min}^{-1}-210^{\circ} \mathrm{C}$ $-1.5 \mathrm{~min} ; 10^{\circ} \mathrm{C} \cdot \mathrm{min}^{-1}-300^{\circ} \mathrm{C}-5 \mathrm{~min}=23.39 \mathrm{~min}$. The temperature of detectors was set at $340^{\circ} \mathrm{C}$, while the temperature of the splitless injector was set at $250^{\circ} \mathrm{C}$. Determinations were made based on the reference solution by Restek Corporation, containing a mix of 16 PAHs (naphthalene, acenaphtylene, fluorene, anthracene, phenathrene, fluoranthene, pyrene, chrysene, and a sum of heavy PAHs: benzo(a)anthracene, benzo(a)pyrene, benzo(b) fluoranthene, benzo(k)fluoranthene, benzo(g,h,i)perylene, indeno(1,2,3-cd)pyrene, dibenzo(a,h)anthracene in a concentration of $2000 \mu \mathrm{g} \cdot \mathrm{cm}^{-3}$ of each component compound. Working solutions equalled 5, 10, 20, 50, 80, $120 \mu \mathrm{g} \cdot \mathrm{cm}^{-3}$ of each of the components. The recovery of PAHs from soil ranged from $84 \%$ to $93 \%$, and was considered separately for each of the compounds analysed.

The sum of light PAHs was composed of naphthalene, acenaphthene, acenaphthylene, fluorene, anthracene, phenathrene, fluoranthene, pyrene and chrysene. The sum of heavy PAHs was made up of benzo(a)anthracene, benzo(a)pyrene, benzo(b)fluoranthene, benzo(k)fluoranthene, benzo(g,h,i)perylene, indeno(1,2,3-cd)pyrene, dibenzo(a,h)anthracene. 
Statistical analysis methods. Statistical processing of the data ${ }^{34}$ was based on an analysis of variance with replicated measurements-3 replications (blocks-B), where two factors: 'FYM fertilisation' $(\mathrm{O})$ and 'differentiated mineral fertilisation' $(\mathrm{M})$ were treated as constants and aggregating, while 'years' (Y; Years) was seen as a factor of the repeated measurements which was identified (involved in) the effect 'crop species'.

$$
y_{i j k l}=\mu+\tau_{i}+f_{k}+(\tau f)_{i k}+\text { Years }_{l}+(\tau \text { Years })_{i l}+(\text { fYears })_{k l}+(\tau f \text { Years })_{i k l}+\beta_{j}+(\beta Y e a r s)_{j l}+\varepsilon_{i j k l}
$$

where: $\mu$ is general mean, $\tau_{i}$ - effect of applying NPK fertilisation and, $f_{k}-$ FYM fertilisation $\mathrm{k}, \beta_{j}$ - effect of a block $\mathrm{j}$, Years 1 - effect of years of the experiment as a factor of repeated measurements, $(\tau f)_{i k}$ - effect of interaction of the $\mathrm{i}^{\text {th }}$ level of NPK fertilisation with $\mathrm{k}-$ FYM fertilisation, $(\tau \text { Years })_{i l}$ - effect of interaction of the $\mathrm{i}^{\text {th }}$ level of NPK fertilisation with $1^{\text {st }}$ year of measurements, $(\text { YYears })_{k l}$ - interaction of $\mathrm{k}$ - FYM fertilisation with 1st year of measurements, $(\beta \text { Years })_{j l}$ - effect of interaction of ith level of NPK fertilisation with $\mathrm{k}$ FYM fertilisation against the background of 1 st year of measurements, $\varepsilon_{i j k l}$ - random experimental error with normal distribution and with the expected value equal zero and variance $\sigma^{2}$.

Prior to making statistical analyses according to the developed model, the assumption of normal distribution of variables within each group was tested. Next, homogeneity of variance in groups was analysed, and additional requirements were accounted for, such as an assessment of sphericity, i.e. the equality of variances of the differences between the measurements. The hypothesis of sphericity was verified by the Mauchley's test. When the violation of sphericity was detected, the multidimensional Wilks' test and Pilai's test were performed. Having conducted the Shapiro-Wilks' test, the assumption of normality of the analysed characteristics was discarded, which led to the application of logarithmic transformation. At the subsequent stage of statistical data processing, post-hoc comparisons were made using the Tukey's test (HSD) at $\mathrm{p}<0.05$. All statistical tests were supported by the software STATISTICA (StatSoft, Inc., 2014).

Received: 25 July 2019; Accepted: 22 February 2020;

Published online: 12 March 2020

\section{References}

1. Abdel-Shafy, H. I. \& Mansour, M. S. M. A review on polycyclic aromatic hydrocarbons: source, environmental impact, effect on human health and remediation. Egypt. J. Pet. 25, 107-123 (2016).

2. Krzebietke, S. Concentration of selected metals in butter lettuce (Lactuca sativa L.) contaminated with anthracene and pyrene. J. Elem. 16(4), 567-576 (2011).

3. Krzebietke, S. \& Sienkiewicz, S. Effect of soil contamination with anthracene and pyrene on yield and accumulation of macronutrients in butter lettuce (Lactuca sativa L.). J. Elementol. 15(4), 653-660 (2010).

4. Krzebietke, S. J. et al. Content of PAHs in soil of a hazel orchard depending on the method of weed control. Env. Monit. Assess. 190, 422, https://doi.org/10.1007/s10661-018-6812-2 (2018).

5. Gupte, A., Tripathi, A., Patel, H., Rudakiya, G. \& Gupte, S. Bioremediation of polycyclic aromatic hydrocarbon (PAHs): A perspective. Open. Biotechnol. J. 10(2), 363-378 (2016).

6. Alexander, M. Biodegradation and bioremediation. 2nd ed. San Diego, USA. Academic Press Inc, pp. 248-250 (1997).

7. Smreczak, B., Klimkowicz-Pawlas, A. \& Maliszewska-Kordybach, B. Biodostępność trwałych zanieczyszczeń organicznych (TZO) w glebach. Bioavailability of persistent organic pollutants in soils. Studia $i$ Raporty IUNG-PI 35(9), 137-153 (2013).

8. Park, K. S., Sims, R. C. \& Dupont, R. The fate of the PAH compounds in two soil types: influence of volatilization of abiotic loss and biological activity. Env. Toxicol. Chem. 9(2), 187-196 (1990).

9. Cerniglia, C. E. Biodegradation of polycyclic aromatic hydrocarbons. Curr. Opin. Biotech. 3((2-3)), 331-338 (1993).

10. Husain, S. Literature overview: Microbial metabolism of high molecular weight polycyclic aromatic hydrocarbons. Remediation J. 18(2), 131-161 (2008).

11. Włóka, D., Kacprzak, M. \& Smol, M. Badanie wpływu skażenia WWA na parametry fizyko-chemiczne gleby. Interdyscyplinarne Zagadnienia w Inżynierii i Ochronie Środowiska (Studies into the effect of pollution with PAHs on physico-chemical parameters of soil) (ISBN: 978-83-7493-836-5), OWP Wrocław: 965-977 (2014).

12. Andreoni, V. \& Gianfreda, L. Bioremediation and monitoring of aromaticpollutedhabitats. Appl. Microbiol. Biotechnol. 76(2), 287-308 (2007).

13. Baklanov, A. et al. Integrated systems for forecasting urban meteorology, air pollution and population exposure. Atmos. Chem. Phys. 7, 55-874 (2007).

14. Ciarkowska, K., Gambuś, F., Antonkiewicz, J. \& Koliopoulos, T. Polycyclic aromatic hydrocarbon and heavy metal contents in the urban soils in southern Poland. Chemosphere 229, 214-226 (2019).

15. Zerbe, J. Zanieczyszczenia środowiska wodnego węglowodorami i ich pochodnymi (Contamination of the water environment with hydrocarbons and their derivatives). Ochrona Środowiska i Zasobów Naturalnych. IOŚ Warszawa 5 (1993).

16. Alexander, M. Aging, bioavailability, and overestimation of risk from environmental pollutants. Env. Sci. Technol. 34(20), 4259-4265 (2000).

17. Boonchan, S., Britz, M. L. \& Stanley, G. A. Degradation and mineralization of high-molecular-weight polycyclic aromatic hydrocarbons by defined fungal-bacterial cultures. Appl. Env. Microbiol. 66(3), 1007-1019 (2000).

18. Boopathy, R. Factors limiting bioremediation technologies. Bioresour. Technol. 74(1), 63-67 (2000).

19. Macleod, C. J. A. \& Semple, K. T. Influence of contact time on extractability and degradation of pyrene in soils. Env. Sci. Technol. 34(23), 4952-4957 (2000).

20. Semple, K. T., Morriss, W. W. J. \& Paton, G. I. Bioavailability of hydrophobic organic contaminants in soils: fundamental concepts and techniques for analysis. Eur. J. Soil. Sci. 54(4), 809-818 (2003).

21. Baran, S., Oleszczuk, P. \& Baranowska, E. Changes of polycyclic aromatic hydrocarbons content in flooded soils. Chem. Inż. Ekol. 11(10), 1111-1120 (2004).

22. Włóka, D., Kacprzak, M. \& Placek, A. Badanie kinetyki procesu biodegradacji wybranych zanieczyszczeń organicznych w glebie. (Studies into the kinetics of biodegradation of some organic contaminants in soil.) Interdyscyplinarne Zagadnienia w Inżynierii $i$ Ochronie Środowiska (ISBN: 978-83-7493-890-7), OWP Wrocław: 468-479 (2015).

23. Maliszewska-Kordybach, B., Klimkowicz-Pawlas, A. \& Smreczak, B. Effects of anthropopressure and soil properties on the accumulation of polycyclic aromatic hydrocarbons in the upper layer of soils in selected regions of Poland. Appl. Geochem. 24, 1918-1926 (2009a). 
24. Maliszewska-Kordybach, B., Smreczak, B. \& Klimkowicz-Pawlas, A. Concentrations, sources, and spatial distribution of individual polycyclic aromatic hydrocarbons (PAHs) in agricultural soils in the Eastern part of the EU: Poland as a case study. Sci. Total. Environ. 407(12), 3746-3753 (2009b).

25. Yang, Y., Woodward, L. A., Li, Q. X. \& Wang, J. Concentrations, Source and Risk Assessment of Polycyclic Aromatic Hydrocarbons in Soils from Midway Atoll, North Pacific Ocean. PLoS One 9(1), e86441, https://doi.org/10.1371/journal.pone.0086441 (2014).

26. Klimkowicz-Pawlas, A., Smreczak, B. \& Ukalska-Jaruga, A. The impact of selected soil organic matter fractions on the PAH accumulation in the agricultural soils from areas of different anthropopressure. Environ Sci Pollut Res., https://doi.org/10.1007/ s11356-016-6610-8 (2016).

27. Marquès, M. et. al. Climate change impact on the PAH photodegradation in soils: Characterization and metabolites identification. Environ Int., 89-90, 155-165, https://doi.org/10.1016/j.envint.2016.01.019, Epub 2016 Feb 6 (2016).

28. Mazur, T., Mazur, Z., Baran, S. \& Oleszczuk, P. Influence of long-term animal slurry, manure and NPK application on polycyclic aromatic hydrocarbon content in soil. Chem. i Inżynieria Ekologoczna 11(8), 749-753 (2004).

29. Zhao, L. et al. Occurrence, sources, and potential human health risks of polycyclic aromatic hydrocarbons in agricultural soils of the coal production area surrounding Xinzhou. China. Ecotoxicol. Env. Saf. 108, 120-128 (2014).

30. Rozporządzenie Ministra Środowiska z dnia 1 września 2016 roku w sprawie sposobu prowadzenia oceny zanieczyszczenia powierzchni (Regulation of the Minister of the Environment of September 1, 2016 on the method of conducting soil pollution assessment). Dz. U. z 2016 r. poz. 1395 (2016).

31. Kabata-Pendias, A. et. al. Podstawy oceny chemicznego zanieczyszczenia gleb. Metale ciężkie, siarka i WWA (Fundamentals of chemical soil pollution assessment. Heavy metals, sulphur and PAHs). Biblioteka Monitoringu Środowiska, PIOŚ, IUNG, Warszawa. 28, 21-25 (1995).

32. Siebielec, G. et. al. Monitoring chemizmu gleb ornych w Polsce w latach 2010-2012 (Monitoring of arable soil chemistry in Poland in 2010-2012). IUNG-PIB. Puławy, pp. 202 (2012).

33. IUSS Working Group WRB, International soil classification system for naming soils and creating legends for soil maps. World Reference Base for Soil Resources 2014, update 2015. World Soil Resources Reports No. 106 (2015).

34. Richter, C. \& Kroschewski, B. Analysis of a long-term experiment with repeated-measurement models. J. Agron. Crop. Sci. 192, $55-71(2006)$

\section{Acknowledgements}

Project financially supported by Minister of Science and Higher Education in the range of the program entitled "Regional Initiative of Excellence" for the years 2019-2022, Project No. 010/RID/2018/19, amount of funding PLN 12.000.000 PLN.

\section{Author contributions}

S.K., E.M.-W. and S.S. conceived and planned the research, S.K. and E.M.-W. carried out the fieldwork and performed the analysis, wrote the manuscript. D.Z. statistical analysis. All authors helped with the interpretation of the results and provided critical feedback on the whole manuscript.

\section{Competing interests}

The authors declare no competing interests.

\section{Additional information}

Correspondence and requests for materials should be addressed to S.K.

Reprints and permissions information is available at www.nature.com/reprints.

Publisher's note Springer Nature remains neutral with regard to jurisdictional claims in published maps and institutional affiliations.

(c) (i) Open Access This article is licensed under a Creative Commons Attribution 4.0 International License, which permits use, sharing, adaptation, distribution and reproduction in any medium or format, as long as you give appropriate credit to the original author(s) and the source, provide a link to the Creative Commons license, and indicate if changes were made. The images or other third party material in this article are included in the article's Creative Commons license, unless indicated otherwise in a credit line to the material. If material is not included in the article's Creative Commons license and your intended use is not permitted by statutory regulation or exceeds the permitted use, you will need to obtain permission directly from the copyright holder. To view a copy of this license, visit http://creativecommons.org/licenses/by/4.0/.

(C) The Author(s) 2020 